\title{
Phenylketonuria felnőttkorban
}

\author{
Sumánszki Csaba dr. - Barta András Gellért oh. - Reismann Péter dr.
}

Semmelweis Egyetem, Általános Orvostudományi Kar, II. Belgyógyászati Klinika, Budapest

\begin{abstract}
A phenylketonuria 1975 óta az újszülöttkori tömegszűrés része. Mára már hazánkban is felnőtt egy olyan generáció, amely születésétôl kezdve speciális diétát tart és orvosi tápszert fogyaszt. A szűrés és a korai terápia bevezetésének köszönhetően a phenylketonuriás gyerekek normális életvitellel bíró felnőtté válhatnak. Ennek köszönhetően a phenylketonuria többé már nem egy gyermekgyógyászati betegség. Ebből adódóan a felnőtt phenylketonuriások ellátása anyagcsere-specializációval bíró belgyógyászati centrumokban történik. Az élethosszig tartó speciális terápia, a phenylketonuria felnőttkori vonatkozásait most ismerjük meg. Az összefoglaló közlemény célja bemutatni a phenylketonuriával kapcsolatos újdonságokat, fókuszálva a felnőttkori vonatkozásokra. Hosszú évek után nemzetközi irányelvek jelentek meg, új terápiás lehetőségek váltak elérhetővé és várhatóak a közeljövőben, új kihívásokkal kell szembenéznünk, mint a maternalis phenylketonuria, a dietoterápia hosszú távú kihatásai vagy a nem kezelt phenylketonuriás felnőttek szövődményei.
\end{abstract}

Orv Hetil. 2017; 158(47): 1857-1863.

Kulcsszavak: phenylketonuria, felnőtt, metabolikus kontroll

\begin{abstract}
Adult phenylketonuria
Starting from 1975 phenylketonuria is part of the newborn screening program in Hungary. Since then a generation, treated with special diet and medical foods right after neonatal diagnosis has reached adulthood. Thanks to early treatment initiation, children with phenylketonuria are able to lead life to the full. Consequently, phenylketonuria is no longer considered a pediatric disease. Follow up of adult patients with phenylketonuria is performed in internal medicine centers specialized in metabolic diseases. The outcome of the lifelong special treatment, and the particularities of phenylketonuria in adulthood are yet to be determined. The aim of our review is to present recent findings in phenylketonuria focusing mainly on the adult care. After long time the first international guidelines appeared, new therapies were put in use, and these current developments are expected to be implemented in daily practice in the near future. New challenges must be met such as maternal phenylketonuria, long term effects of dietotherapy and the sequelae of untreated phenylketonuria in adulthood.
\end{abstract}

Keywords: phenylketonuria, adult, metabolic control

Sumánszki Cs, Barta AG, Reismann P. [Adult phenylketonuria]. Orv Hetil. 2017; 158(46): 1857-1863.

(Beérkezett: 2017. augusztus 12.; elfogadva: 2017. szeptember 14.)

\section{Rövidítések}

$\mathrm{AAVV}=($ adeno-associated viral vector $)$ adenoasszociált virális vektor; $\mathrm{BH}_{4}=$ (tetrahydrobiopterin) tetrahydrobiopterin; $\mathrm{BMD}=($ bone mineral density $)$ csontsürüség; ETPKU $=($ earlytreated phenylketonuria) korán kezelt phenylketonuria; GMP $=($ glycomacropeptide $)$ glikomakropeptid; LNAA $=$ (large neutral amino acids) nagy neutrális aminosavak; MRI = (magnetic resonance imaging) mágneses rezonanciás vizsgálat; $\mathrm{PAH}=$ (phenylalanine hydroxylase) fenilalanin-hidroxiláz; $\mathrm{PAL}=$ (phenylalanine ammonia-lyase) fenilalanin-ammónia-liáz; Phe $=$ (phenylalanine $)$ fenilalanin; PKU $=$ (phenylketonuria $)$ phenylketonuria; $\mathrm{QOL}=$ (quality of life $)$ életminőség; Trp $=$ (tryptophan) triptofán; TYH = (tyrosine hydroxylase $)$ tirozinhidroxiláz; $\mathrm{Tyr}=($ tyrosine $)$ tirozin; $\mathrm{WMA}=($ white matter $\mathrm{ab}-$ normalities) fehérállomány-károsodások

A phenylketonuria (PKU) egy veleszületett anyagcserezavar, amely a fenilalanin-hidroxiláz enzim (PAH) defektusának következtében a fenilalanin (Phe) tirozinná (Tyr) alakulásának zavarával jár. Emiatt a fenilalanin, illetve toxikus metabolitjai (fenil-ketonok) a vérben és a különböző szervekben kóros mértékben felszaporodnak, 
a legtöbb esetben irreverzibilis károsodást okoznak. A PKU-ban kialakuló enzimblokk következtében a Tyrból képződő monoaminerg neurotranszmitterek (dopamin, noradrenalin), hormonok (tiroxin és trijód-tironin) és a melanin szintje csökkenhet [1].

Hazánkban hozzávetőlegesen 1:8500 a PKU előfordulási gyakorisága, a heterozigóta hordozók aránya 1:50. $\mathrm{Az}$ újszülöttkori tömegszúrés bevezetésével Magyarországon évente 8-9 PKU-s újszülöttet szúrnek ki. A jelenlegi hazai és nemzetközi ajánlások alapján a diagnózist követően élethosszig tartó fenilalanin-szegény diéta tartása javasolt [2]. Azon PKU-s egyéneket, akiket az újszülöttkori tömegszűrésen emeltek ki, és azóta dietoterápiában részesülnek, korán kezelt PKU-snak nevezzük (early-treated PKU: ETPKU). A terápia ugyan segít megelőzni a súlyos neurológiai és pszichiátriai szövődményeket, de szorosan betartott diéta mellett is jelentkezhetnek szervi diszfunkciók. Az életre szóló, szigorú fehérjeszegény diéta és mesterséges Phe-mentes aminosavtápszerek fogyasztásának hosszú távú kihatásai ma még nem teljesen ismertek.

\section{Szürés}

A Robert Guthrie által felfedezett szürőpapírteszt kifejlesztését követően az 1960-as évek közepén világszerte elkezdődött a PKU-szűrő programok bevezetése [3]. Hazánkban dr. Szabó Lajos munkásságának köszönhetően a Szegedi Gyermekklinika körzetében 1968-ban bevezették az újszülöttkori szürést [4]. 1975-ben az Egészségügyi Minisztérium rendelete - 5/1975. (V.28.) EüM-rendelet - kötelezővé tette országos szinten is a szûrés bevezetését [5]. Az ETPKU-s újszülöttek a születést követő egy hétben elkezdett fehérjeszegény diétájának és az orvosi tápszerekkel való Phe-mentes aminosav pótlásának köszönhető, hogy a korábban gyakran észlelt súlyos mentális retardáció előfordulása csökkent, és a kezelt PKU-s betegek normális életvitellel bíró felnőtteké válhattak [6].

A PKU-s egyének gondozása hazánkban két centrumban történik: a Szegedi Tudományegyetem SzentGyörgyi Albert Klinikai Központ Gyermekgyógyászati Klinikáján és a Semmelweis Egyetem I. Gyermekgyógyászati, valamint II. Belgyógyászati Klinikáján. Az utóbbi években vált Európában is egyre elterjedtebbé, hogy a felnőttkorba lépő PKU-s egyéneket többé nem a gyermekgyógyászati központ gondozza tovább, hanem anyagcsere-specializációval bíró belgyógyászati centrum. A Semmelweis Egyetemhez tartozó régióban 2011 óta a 18. életévet betöltött PKU-s páciensek gondozását a II. Belgyógyászati Klinika vette át. Jelenleg közel 140 ETPKU-s felnőttet lát el a budapesti felnőttgondozó központ, ami nemzetközi összehasonlításban kiemelten nagy számnak tartható [7].

Az ETPKU-s felnőttek gondozása több szempontból jelent kihívást. Mivel az első, már újszülöttkora óta kezelt populáció most éri el a negyvenes életkort, nincs sem hazai, sem nemzetközi számottevő tapasztalat vagy klinikai vizsgálat a kezelt PKU, az élethosszig tartó fehérjeszegény diéta vagy a mesterséges aminosavtápszer késői kihatásairól. Kevés az ebben a témában rendelkezésre álló irodalmi adat, a nemzetközi ajánlások gyenge bizonyítékokon alapulnak, nagyon sok esetben gyermekgyógyászati tapasztalatokat használtak fel [8].

\section{A PKU csoportosítása}

A hyperphenylalaninaemia felosztásánál elsődleges elkülöníteni a PAH-enzim vagy kofaktorának defektusából kialakuló betegségcsoportokat. A fenilalanin-hidroxiláz enzim teljes vagy részleges zavarának következménye a klasszikus PKU, az enyhe PKU vagy az enyhe hyperphenylalaninaemia. A PAH enzim kofaktorának, a $\mathrm{BH}_{4}$ szintézisének vagy újrahasznosításának zavara úgynevezett atípusos PKU-t okoz [9].

A PKU súlyosság alapján történő csoportosítása korábban a születést követő, nem kezelt, úgynevezett csúcsPhe-szint alapján történt. Egészséges egyénekben a vér Phe-szintje 50-60 بmol/1 körüli. Az $1200 \mu \mathrm{mol} / 1$ feletti vér Phe-szintek klasszikus PKU-ra jellegzetesek, általában teljes enzimdefektus következményei. A 600 és 1200 umol/l vér Phe-szinteket enyhe PKU-csoportba soroljuk. Egy friss amerikai ajánlás ezt a csoportot továbbosztja mérsékelt és enyhe PKU-csoportra, ahol az előző csoport a

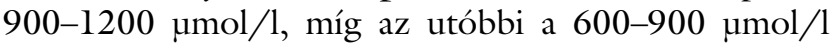
vérszinttel bírókat foglalja magában. Normális diéta melletti 360-600 $\mu \mathrm{mol} / \mathrm{l}$ vér Phe-szint közötti értékek a byperphenylalanaemia szürke zónáját jelentik, míg a 360 $\mu \mathrm{mol} / 1$ alatti szintekkel bírók a nem kezelendó enyhe hyperphenylalaninaemia-csoportba sorolandóak [8]. A tömegszưrés hatékonyságának köszönhetően azonban napjainkban olyan gyorsan kiemelik az érintett újszülöttet, hogy a fehérjeszegény diéta előbb kerül bevezetésre, mint hogy a vér Phe-szintje elérné a maximális értéket. Ezért a PKU-alcsoportba történő besorolás a vér Phe-szint mellett a $\mathrm{BH}_{4}$-terhelésre adott válasz, valamint a Phe-tartalmú élelmiszerek toleranciáján is alapul [8].

A PAH gén közel 1000 mutációját írták eddig le, ezeknek 60\%-a egyetlen nukleotidot érintő pontmutáció [10]. A PAH-mutációk, valamint klinikai jelentőségük a BIOPKUdb online adatbázisán keresztül elérhetők (http://www.biopku.org). Sok mutációval kapcsolatban már ismert a genotípus-fenotípus korreláció, azaz milyen a residualis enzimaktivitás vagy az illető fogékonysága különböző terápiás lehetőségekre. Magyarországon a leggyakoribb genetikai eltérés a körülbelül 75\%-ban előforduló R408W-pontmutáció, amely klasszikus PKU-t eredményez közel 0\%-os enzimaktivitással $[4,10,11]$.

A magas Phe-szinttel járó kórképek csupán 2\%-a atipikus PKU, amely a $\mathrm{BH}_{4}$-szintézis és -újrahasznosítás zavara következményeként kialakuló másodlagos PAH-hiány. Elkülönítése fontos a PAH enzim elsődleges zavarától, ugyanis nem igényel diétát, és a kofaktorpótláson túl kezelése jelentősen eltér a klasszikus PKU-étól [12]. 


\section{Kezelés}

Míg a XX. században a PKU standard kezelése a serdülőkorban véget ért, a 2000-es évek elején fogalmazódott meg az élethosszig tartó diéta szükségessége [2, 13]. A PKU-s egyének számára ma az egyik legnagyobb kihívást az egész életen át tartó diéta jelenti. A természetes fehérjében szegény diéta segítségével lehetséges a vér Phe-szinteket a szükséges minimumra korlátozni. Az egyéni variabilitást mutató Phe-tolerancia meghatározza a diéta szigorúságát. Klasszikus PKU-ban maximum 350-500 mg jelenti a napi Phe-fogyasztás felső határát. Ez a diéta minden állati eredetű fehérje, magas fehérjetartalmú zöldségek, gyümölcsök és magok fogyasztását megtiltja, valamint csak korlátozott mennyiségben fogyaszthatók pékáruk, tésztafélék, rizsfélék [14]. A szénhidrát és zsírok mellett keményítőalapú kenyér és tésztafélék jelentik a fö energiaforrást. Elégtelen energiabevitel a saját fehérjekatabolizmus következményeként tovább növelheti a vér Phe-szintet, ezért kerülendő [15]. A diéta hatékonyságának ellenőrzése a vér Phe-szintjének kontrollálásával, diétásnapló vezetésével lehetséges. A szükséges aminosavak, valamint mikro-, makroelemek és vitaminok pótlása speciális, Phe-mentes aminosavkészítményekkel, úgynevezett orvosi tápszerek fogyasztásával történik. A tápszerek napi rendszerességgel, testsúlyra számított mennyiségben fogyasztandók [16]. Nem megfelelő pótlás esetén különböző hiányállapotok jelentkezhetnek, amelyek közül a leggyakoribb a Tyr, a $\mathrm{B}_{12^{-}}, \mathrm{B}_{6^{-}}$ vitamin, a vas, a folsav, a cink és a szelén hiánya [16]. $\mathrm{A} \mathrm{Ca}^{2+}$ és a D-vitamin pótlása nemcsak hiányállapotban, hanem csökkent csontsűrüség esetén is szükséges [14]. A beteg számára nemcsak az adja a kihívást, hogy a „tiltott” ételeket ne fogyassza, hanem az orvosi tápszerek mindennapi elfogyasztása is, mivel a tápszerek ízét, fogyaszthatóságát befolyásolja a nagy koncentrációjú aminosav.

\section{Határértékek}

A leggyakoribb és legszélesebb körben elfogadott ellenőrzési metodika a megadott időközönkénti vér Pheszint-monitorizálás. Míg csecsemő-, kisgyermekkorban akár hetente többször, felnőttkorban havi egy alkalommal javasolt szürőpapírt küldeni a gondozóközpontba. A céltartományok életkortól függően változnak. Míg korábban igen nagy eltérést mutatott egy-egy ország, állam által javasolt céltartomány, az elmúlt két évben jelent meg külön-külön amerikai, illetve európai irányelv, amely egységes céltartomány megadását javasolta. Míg az amerikai ajánlás egy szigorú, születéstôl élethosszig betartandó, $360 \mu \mathrm{mol} / 1$ alatti szintet tart biztonságosnak, addig az európai ajánlás felnőttekre vonatkozó része 600 umol/l alatti céltartományt javasolt $[12,16]$. Egyértelmü adatok vannak arra vonatkozóan, hogy 360 pmol/1 átlagos szint alatt tartós neurológiai tünetek nem alakulnak ki, valamint arra, hogy $600 \mu \mathrm{mol} / 1$ feletti tartós vér
Phe-szintek neurokognitív és pszichiátriai zavarokhoz vezetnek. A 360-600 $\mu \mathrm{mol} / 1$ közötti vér Phe-szintekhez köthető tartós károsodásokkal kapcsolatban alig van jó minőségű tanulmány [16].

Fontos megemlíteni, hogy a vér Phe-szint monitorizálása egy „surrogate” markernek tekintendő, hiszen a célszervkárosodást okozó szerven belüli Phe-szinteket mérni rutin klinikai módszerekkel jelenleg nem tudjuk (például: agyi Phe-koncentráció); szintén nincs adekvát módszer a vér Phe-szint fluktuációjának ellenőrzésére, amely egyes tanulmányok szerint szorosabb kapcsolatot mutathat a célszervkárosodásokkal és neuropszichológiai eltérésekkel [7, 17].

\section{A betegséggel kapcsolatos szövődmények}

A PKU okozta magas fenilalanin-szint az agymúködést károsítja. Bár a pontos mechanizmus a mai napig nem teljesen tisztázott, néhány kulcslépése már ismert. A Phe más nagy, neutrális aminosavakkal együtt egy aktív transzporter (L-type amino acid transporter 1-4 - LAT 1-4) segítségével képes a vér-agy gáton az agyba átjutni. Magas vér fenilalanin-szint kompetitív módon gátolja más neurotranszmitter prekurzor (például: tirozin, triptofán - Trp) átjutását a vér-agy gáton, csökkentve, illetve megváltoztatva ezzel az agyi neurotranszmitter elérhetőségét. A Tyr és Trp a központi idegrendszerben dopamin, noradrenalin és szerotonin monoaminerg neurotranszmitterek előterméke. Az aminosavtranszportkompetencián túl a magas agyi Phe-koncentráció direkt toxikus hatással bírhat az agysejtekre [18, 19]. Ismert azonban, hogy azonos szintü vér Phe-értékek mellett az idegrendszeri tünetek egyénenként eltérő változatosságot mutatnak, amelyben szerepe lehet különböző genetikai faktoroknak, a Phe-fluktuációnak, a különböző Tyrellátottságnak $[20,21]$.

\section{Neuropszichiátriai eltérések}

A felnőttkori neurológiai és pszichiátriai tünetek súlyosságát alapvetően befolyásolja a kisgyermek-tinédzser kori diétahűség és az élethosszra számított vér Phe-szint. Tanulmányok metaanalízise alapján felnőttkorban a 600 umol/l feletti Phe-értékek mellett válnak gyakoribbá a neurológiai és a pszichiátriai tünetek [19]. Képalkotó, döntően mágneses rezonanciás vizsgálatok fehérállomány-károsodásokat mutattak ki rosszul kezelt PKU-s egyénekben [20]. Spektroszkópiás mágneses rezonanciás vizsgálatok lehetôvé teszik az agyi Phe- és Tyr-szintek noninvazív meghatározását. Az agyi Phe növekedése és Tyr-szint csökkenése negatív összefüggést mutat a verbális emlékezettel, és pozitívan függ össze a szorongással és a végrehajtó funkció zavarának mértékével [21].

A neurológiai tünetek széles skálán mozognak, minor tünetek a végtagremegés, az élénkebb reflexek és a romló motoros koordináció $[16,22,23]$. Kezeletlen PKUban súlyos neurológiai elváltozások észlelhetőek, mint 
spasticus paraparesis, epilepszia, ataxia, corticalis vakság. A diéta újbóli bevezetése kedvező hatással bír mind a neurológiai tünetekre, mind a fehérállományi károsodásokra [16].

A pszichiátriai tünetek közül kiemelendő a végrehajtó funkció, a célirányos viselkedés megtervezésének és kivitelezésének zavara, az alacsony verbális memória és fogékonyság, valamint a csökkent szociális és érzelmi készség. Egyéb pszichiátriai tünet a depresszió, a különbözó fóbiák és a szorongás, amely fóleg az élet harmadik és negyedik évtizedében jelentkezik [23].

Az emelkedett Phe-szintek mellett megfigyelt neurokognitív zavarok tovább nehezítik a betegek diétatartását és tápszerfogyasztását, továbbá jelentősen csökkentik az életminőséget (QOL). Újabban PKU-ra specifikus validált európai kérdőívek is elérhetővé váltak, amelyek képesek korcsoportokra bontva felmérni az egészséggel összefüggő életminőségi problémákat a betegek körében [24]. Ezen kérdőívek alapján a Phe-szegény diétát elhagyó egyénnél a diéta visszaállítása az életminőséget jelentôs mértékben képes javítani [25].

\section{Diétával összefüggést mutató szövődmények}

\section{Csontanyagcsere-eltérések}

A csökkent csontsűrűség jelenléte gyakoribb a PKU-s betegek körében az átlagpopulációhoz képest [26]. Számos vizsgálatot követően sem egyértelmű még a Pheszint és a csontanyagcsere kapcsolata [27]. A csontanyagcserét, valamint a csontsürüséget nemcsak maga a PKU, a toxikus metabolitok, hanem a természetes fehérjében szegény és vitaminban/nyomelemben módosított terápia is jelentősen befolyásolhatja [27]. Ez idáig mindössze csak egy vizsgálatnak sikerült igazolni emelkedett csonttörési kockázatot [28]. Nem szabad figyelmen kívül hagyni azt, hogy a PKU-s felnőttek egy fiatal betegcsoportot képviselnek, akik az egészséges populációra meghatározott csúcscsonttömeget sokszor nem érik el. Ennek klinikai relevanciája még kérdéses, ezért szoros utánkövetést igényel a későbbi életkorban.

\section{Vitamin-és mikroelembiány, illetve túlzott bevitel}

A természetes fehérjében szegény diéta az állati eredetú fehérjéből származó vitaminok és mikroelemek hiányát okozza. A legszélesebb körben a $\mathrm{B}_{12}$-vitamin hiányát tanulmányozták PKU-ban. A súlyos, hosszan tartó $\mathrm{B}_{12^{-}}$ hiányállapot a neurológiai és pszichiátriai tünetek mellett glossitist, anaemiát és szívmúködési zavarokat okozhat [29]. A csontanyagcsere szempontjából a nem elégséges D-vitamin- és kalciumbevitel csökkentheti a csontsűrüséget [26]. Ritkábban előfordulhat folsav-, $\mathrm{B}_{6^{-}}$, vas-, szelén-, cinkhiány [30]. Az aminosavak, mik- roelemek, vitaminok pótlása Phe-mentes orvosi tápszerekkel történik. A hiányállapotok a diétát tartó, azonban az orvosi tápszereket rendszertelenül fogyasztó egyéneket fenyegeti. A tápszerfogyasztás elmaradása felnőttPKU-ban sokkal gyakoribb a gyermekpopulációhoz képest. Ennek számos oka van, egyrészt a szülői ellenőrzés csökkenése, elmaradása, a mindennapi tevékenység (munka) ritmusában elfelejtik elfogyasztani a tápszert, valamint a tápszerek kellemetlen ízérzete miatti csökkent adherencia. Sokkal ritkábban fordul elő, hogy a diétát nem tartó, de orvosi tápszereket túlzott, ellenőrizetlen mennyiségben fogyasztó PKU-s egyénben bizonyos nyomelemek, ásványi anyagok és vitaminok toxikus szintet érnek el [31].

\section{Maternalis $P K U$}

A phenylketonuria nem befolyásolja a termékenységet. A Phe átjut a placentán, és az emelkedett Phe-szintnek súlyos magzatkárosító hatása van. Ez a maternalis PKUszindróma. A magzatot érintő leggyakoribb károsodások a szellemi visszamaradás, a facialis dysmorphiák, a microcephalia, az intrauterin fejlődés elmaradása és a szívfejlődési rendellenességek [32]. A teratogén hatások összefüggést mutatnak az anyai vér Phe-szintjével, 1200 $\mu \mathrm{mol} / \mathrm{l}$ felett a microcephalia és a mentális érintettség 90\%-ban, a méhen belüli növekedési visszamaradás 40\%ban, a szívfejlődési rendellenesség pedig 15\%-ban fordul elő. A 600-1200 ㅆmol/1 Phe-értékek között a teratogén hatások valamivel ritkábbak [33]. Kiemelendő, hogy amennyiben az apa nem hordozza a PKU-gént, az anyai magas Phe-szintek ekkor is károsítják a genetikailag egészséges magzat fejlődését. A fehérjehiányos állapot a magzat fejlődését károsíthatja, ezért a $120 \mu \mathrm{mol} / 1$ alatti Phe-szintek szintén kerülendőek. Az anya stabil súlygyarapodása kedvező hatással bír a várandósság kimenetelére, ennek érdekében a megfelelő energiabevitel elengedhetetlen. Az európai ajánlás a várandósság alatti céltartományt 120-360 $\mu \mathrm{mol} / \mathrm{l}$ között jelölte ki, ebben a tartományban a legvalószínúbb, hogy az újszülöttet nem éri károsodás. A fogamzás így PKU-s hölgyeknél csak tervezetten javasolt, a várandóssági céltartomány elérése után két héttel javasolt a fogamzásgátlás elhagyása [16]. A várandósság alatt gyakoribb vérszintellenőrzés szükséges a tápszer fogyasztása elengedhetetlen. A szoptatás PKU-s anya esetében nem tiltott, viszont ha a gyerek is örökölte a betegséget, szoros Phe-szint-monitorizálást követel mind az anyánál, mind pedig az újszülöttnél [16]. Magas kockázatú várandósság esetén, ahol az anya vér Phe-szintjei meghaladják a megengedett tartományt, kiegészítő foetalis ultrahangot javasolnak a 18-22. héten a magzatkárosodások felderítése érdekében [16]. A maternalis PKU szindróma megelőzése érdekében Magyarországon 1994 óta prevenciós program biztosítja a 12 évesnél idősebb PKU-s lányok időszakos felvilágosítását [32]. 


\section{Kezeletlen PKU}

A tömegszürés bevezetése előtt született vagy bevándorló PKU-s betegek a későn elkezdett diéta vagy a diéta teljes hiányának következtében súlyos, maradandó neurológiai és pszichiátriai károsodásokkal élnek. Bár tanulmányok alapján igazolt, hogy az ilyen betegeknél a diéta visszaállításával bizonyos mértékig javítható a neurológiai és pszichiátriai státusz, enyhíthetők a motoros tünetek, epilepsziás rohamok, viselkedési és hangulati zavarok, a már meglevő, visszafordíthatatlan károsodások negatívan befolyásolják a compliance-t és az adherenciát [34]. A fentieket figyelembe véve az európai ajánlás egyéni mérlegelés alapján hat hónapos próbadiétát javasol [16].

\section{Új kezelési lehetőségek, utánkövetés}

\section{Diétás terápiák}

A dietoterápia tökéletesítése a mai napig központi helyet foglal el a PKU kezelésében. A tápszerek ízének, állagának, fogyaszthatóságának fejlesztésével növelhető a tápszerfogyasztási adherencia.

Alternatív fehérjepótló lehetőségként jön szóba a glikomakropeptid (GMP), amely sajtokból kivont 64 aminosavból álló glikofoszfopeptid. Különlegessége, hogy magas fehérjetartalma ellenére tisztított formában kevés Phe-t tartalmaz (2-5 mg Phe per gramm fehérje) [14]. Alacsony tirozin-, triptofán-, arginin-, cisztein- és hisztidintartalma miatt alkalmazása csak aminosavkészítmények társításával javasolt [35]. Előnye, hogy íze kellemesebb, és nagyobb jóllakottságérzést kelt az aminosavkészítményekhez képest. Hosszú távú alkalmazásáról, valamint az immunválaszra gyakorolt hatásáról nem áll rendelkezésre még kellő információ, ezért még nem javasolják az ajánlások $[8,16]$. Hazánkban egyelőre még nem elérhető.

A nagy neutrális aminosavak (LNAA) a Tyr, a Phe, a Trp, a metionin, az izoleucin, a treonin, a valin, a leucin és a hisztidin. A Phe-mentes LNAA-keveréket tartalmazó készítmények orális úton történő alkalmazása egyrészt csökkentheti a vér Phe-szintet azáltal, hogy kompetitív módon gátolja a Phe bélből történő felszívódását, másrészt a vér-agy gáton átjutó Phe csökkentésével, valamint a cerebralis Tyr- és Trp-szintek növelésével javítja az aminosav-egyensúlyt a központi idegrendszerben [3639]. Alkalmazása szigorú körültekintést igényel. A jelenlegi ajánlások a diétát nem tartó serdülők és felnőttek körében, valamint kezeletlen PKU-ban javasolja használatát [39].

\section{Nem diétás terápiás fejlesztések}

Farmakoterápiás megközelítést jelent a 2008-tól az Európai Gyógyszerügynökség által jóváhagyott szintetikus $\mathrm{BH}_{4}$ koenzim, a sapropterin-dihidroklorid orális úton történő adása. A sapropterin mint egy farmakológiai chaperon stabilizálni képes a residualis enzimaktivitással bíró, mutáns PAH enzimet, ezáltal növelni képes az aktivitását [16]. A kezelés előfeltétele a pozitív sapropterinterheléses teszt, amelynek során sapropterin alkalmazását követően csökken a vér Phe-szint, vagy növekszik a diétás Phe-tolerancia stabil vérszint mellett [40-42]. Klaszszikus PKU-t okozó, 0\% enzimaktivitással járó mutációk esetében a sapropterinterápia nem bizonyult hatékonynak a Phe-szintek csökkentésében $[41,43]$. A sapropterinkezelésben részesülő betegeknél lazább diéta betartása is elegendő a megfelelő metabolikus kontrollhoz, növelve ezáltal a terápia-, illetve a diétahűséget [44].

A fenilalanin-ammónia-liáz (PAL) (EC 4.3.1.24) egy bakteriális eredetú enzim, amely a Phe-t ammóniára és transzfahéjsavra bontja. A fahéjsav vagy végterméke, a benzoesav glicinnel konjugálódva a vizelettel ürül ki a szervezetből. A PAL képes csökkenteni a Phe-szintet a PAH-mutációval bíró egyénekben is. Vérszintcsökkentő hatása független a diétától. Polietilén-glikolhoz (PEG) kapcsolt formája bőr alatti injekcióként hatékonynak bizonyult a preklinikai vizsgálatokban, 2013 óta a fázis III. vizsgálata folyik. Bár a PAL-terápia hatékonyan csökkenti a vér Phe-szintet, a kezelésben részt vevőknél a készítménnyel szemben ellenanyagok jelentek meg, így klinikai relevanciája egyelőre kérdéses $[45,46]$.

\section{Etiológiai terápiás fejlesztések}

A PKU esetében a májátültetés végleges gyógyulást jelentene. A PKU életet nem veszélyeztető voltát tekintve a beavatkozás és az ezt követő immunszuppresszív terápia túlságosan radikálisnak tűnik a diétás kezeléssel szemben. A májsejtátültetés az előbbivel ellentétben nem igényel sok mellékhatással járó immunterápiát. Sikeres állatkísérleteket követően az első humán vizsgálatot 2016-ban zárták le [47]. A beavatkozás minimális invazivitással járt, és potenciálisan ismételhető, így alkalmas lehet azon betegek kezelésére, akiknél a mentális érintettség miatt a diéta tartósan nem betartható [48].

Mivel a PKU monogénes betegség, a génterápia egy lehetséges kezelési alternatíva lehet. Az első sikeres génterápiás beavatkozást PKU-egérmodellen végezték rekombináns adenoasszociált virális vektort (AAVV) használva [49]. A génszerkesztés egy újabb módja kevesebb géntoxicitással, hosszabb transzgénexpresszióval rendelkező úgynevezett minicircle (MC) DNS-vektoron keresztül valósult meg ebben az évben szintén egérmodellen $[50]$.

\section{Következtetések}

A PKU ellátása Magyarországon sikertörténetnek számít. A hatékony újszülöttkori szúrőprogramnak, az érintettek gyors kiemelésének és a korai diéta bevezetésének köszönhetően egyre több, súlyos szövődménytől mentes PKU-val élő páciens kerül át felnőttgondozásba. Az újszülöttkoruk óta jól kezelt ETPKU-s páciensek teljes 
értékű életet élhetnek, családjuk lesz, mind a tanulmányokban, mind a munkahelyükön az egészséges társaikhoz mérhető teljesítményt érhetnek el.

A felnőttkori PKU új kihívásokat vont maga után. A maternalis PKU szindróma elkerülése tekinthető az egyik legfontosabb célkitűzésnek, amelynek kulcsa az idejében elkezdett edukáció, valamint a rendszeres kontroll és a diétahüség fenntartása.

Nem megfelelő felnőttkori adherencia és compliance esetén kezdetben szubklinikai, majd manifeszt kognitív és pszichiátriai zavarok alakulhatnak ki. A hangulatzavar, különböző fóbiák, szorongás megjelenése vagy a végrehajtó funkciók károsodása jelentősen ronthatja a beteg életminőségét, sok esetben a munkájának elvesztéséhez is vezethet. Időszakosan elvégzett, célzott neurológiai vizsgálatok idejekorán jelezhetik a végrehajtó funkciókban bekövetkező változást.

A gyerekkorban már észlelhető alacsony csontsűrűség alacsony csúcscsonttömeget eredményez felnőttkorban, amelynek klinikai relevanciája a mai napig nem tisztázott, emiatt szoros utánkövetést igényel.

A szưrőprogramok előtt született vagy kisgyermekkoruk óta kezeletlen PKU-s betegek súlyos neurológiai, pszichiátriai és egyéb szervi károsodással érik el a felnőttkort. A legtöbbjük önálló életvitelre nem képes. Bár a nemzetközi tanulmányok a diéta bevezetését követően mérsékelt javulást mutattak a betegek életminőségében, illetve klinikai állapotukban, azonban a súlyos mentális retardáció nagyon megnehezíti a diéta tartós fenntartását.

Az aktuális hazai és európai ajánlás alapján a 18 év feletti betegeknél a biztonságos vér Phe-szint $600 \mu \mathrm{mol} / 1$ alatti. Jelenleg hazánkban ez Phe-szegény diétával és rendszeres orvositápszer-fogyasztással tartható fenn. Bár a sapropterin elérhető itthon, jelenleg felnőtt PKU-s betegnél még nem került alkalmazásra. Az LNAA vagy GMP várhatóan a következő években válik Magyarországon elérhetővé. A fehérjeszegény diétához kapcsolódó adherencia felnőttkorban jelentősen fluktuál, ezért a nem diétához kötött Phe-szintet csökkentő kezelési lehetőségek (enzimterápia, májsejt-transzplantáció és génterápia) a felnőtt PKU-s populációban is alkalmazható lehet majd.

Anyagi támogatás: A közlemény megírása, illetve a kapcsolódó kutatómunka anyagi támogatásban nem részesült.

Szerzői munkamegosztás: S. Cs.: A kézirat megszövegezése, az irodalom összeállítása. B. A. G. : Az összefoglaló kialakításában való részvétel. R. P.: Az összefoglaló kialakításában való meghatározó részvétel, a cikk végleges formájának megvalósítása.
A cikk végleges változatát mindhárom szerző elolvasta és jóváhagyta.

Érdekeltségek: A szerzőknek nincsenek érdekeltségeik.

\section{Irodalom}

[1] Erlandsen H, Stevens RC. The structural basis of phenylketonuria. Mol Genet Metab. 1999; 68: 103-125.

[2] National Institutes of Health, Consensus Development Conference Statement: phenylketonuria: screening and management, October 16-18, 2000. Pediatrics 2001; 108: 972-982.

[3] Guthrie R, Susi A. A simple phenylalanine method for detecting phenylketonuria in large populations of newborn infants. Pediatrics 1963 ; 32: 338-343.

[4] Szabó L, Havass Z, Soltysiak J, et al. Phenylketonuria screening in Hungary. [Phenylketonuria szürővizsgálatok Magyarországon.] Orv Hetil. 1974; 115: 498-504. [Hungarian]

[5] Schuler A, Somogyi C, Toros I, et al. Twenty years of experience with phenylketonuria in Hungary. Int Pediatr. 1996; 11: 114117.

[6] Moyle JJ, Fox AM, Arthur M, et al. Meta-analysis of neuropsychological symptoms of adolescents and adults with PKU. Neuropsychol Rev. 2007; 17: 91-101

[7] Trefz FK, van Spronsen FJ, MacDonald A, et al. Management of adult patients with phenylketonuria: survey results from 24 countries. Eur J Pediatr. 2015; 174: 119-127.

[8] Camp KM, Parisi MA, Acosta PB, et al. Phenylketonuria Scientific Review Conference: State of the science and future research needs. Mol Genet Metab. 2014; 112: 87-122.

[9] Feillet F, van Spronsen FJ, MacDonald A, et al. Challenges and pitfalls in the management of phenylketonuria. Pediatrics 2010; 126: 333-341.

[10] Patel D, Kopec J, Fitzpatrick F, et al. Structural basis for liganddependent dimerization of phenylalanine hydroxylase regulatory domain. Sci Rep. 2016; 6: 23748.

[11] Guldberg P, Rey F, Zschocke J, et al. A European multicenter study of phenylalanine hydroxylase deficiency: classification of 105 mutations and a general system for genotype-based prediction of metabolic phenotype. Am J Hum Genet. 1998; 63: 7179.

[12] Vockley J, Andersson HC, Antshel KM, et al. Phenylalanine hydroxylase deficiency: diagnosis and management guideline. Genet Med. 2014; 16: 188-200.

[13] Koch R, Burton B, Hoganson G, et al. Phenylketonuria in adulthood: a collaborative study. J Inherit Metab Dis. 2002; 25: 333346.

[14] Van Calcar SC, MacLeod EL, Gleason ST, et al. Improved nutritional management of phenylketonuria by using a diet containing glycomacropeptide compared with amino acids. Am J Clin Nutr. 2009; 89: 1068-1077.

[15] Cleary M, Walter JH. Assessment of adult phenylketonuria. Rev Artic Ann Clin Biochem. 2001; 38: 450-458.

[16] Van Spronsen FJ, van Wegberg AM, Ahring K, et al. Key European guidelines for the diagnosis and management of patients with phenylketonuria. Lancet Diabetes Endocrinol. 2017; 5: 743-756.

[17] Maillot F, Lilburn M, Baudin J, et al. Factors influencing outcomes in the off spring of mothers with phenylketonuria during pregnancy: the importance of variation in maternal blood phenylalanine. Am J Clin Nutr. 2008; 88: 700-705.

[18] Martynyuk AE, van Spronsen FJ, Van der Zee, EA. Animal models of brain dysfunction in phenylketonuria. Mol Genet Metab. 2010; 99(Suppl 1): S100-S105. 
[19] Fonnesbeck CJ, McPheeters ML, Krishnaswami S, et al. Estimating the probability of IQ impairment from blood phenylalanine for phenylketonuria patients: a hierarchical meta-analysis. J Inherit Metab Dis. 2013; 36: 757-766.

[20] Leuzzi V, Tosetti M, Montanaro D, et al. The pathogenesis of the white matter abnormalities in phenylketonuria. A multimodal 3.0 tesla MRI and magnetic resonance spectroscopy (1H MRS) study. J Inherit Metab Dis. 2007; 30: 209-216.

[21] Waisbren SE, Prabhu SP, Greenstein P, et al. Improved measurement of brain phenylalanine and tyrosine related to neuropsychological functioning in phenylketonuria. JIMD Rep. 2017; 34: 77-86.

[22] Pietz J, Dunckelmann R, Rupp A, et al. Neurological outcome in adult patients with early-treated phenylketonuria. Eur J Pediatr. 1998; 157: 824-830.

[23] Hanley WB. Adult phenylketonuria. Am J Med. 2004; 117: 590-595

[24] Bosch AM, Burlina A, Cunningham A, et al. Assessment of the impact of phenylketonuria and its treatment on quality of life of patients and parents from seven European countries. Orphanet J Rare Dis. 2015; 10: 80 .

[25] Bik-Multanowski M, Didycz B, Mozrzymas R, et al. Quality of life in noncompliant adults with phenylketonuria after resumption of the diet. J Inherit Metab Dis. 2008; 31(Suppl 2): S415S418

[26] Hansen KE, Ney D. A systematic review of bone mineral density and fractures in phenylketonuria. J Inherit Metab Dis. 2014; 37: 875-880.

[27] Demirdas S, Coakley KE, Bisschop PH, et al. Bone health in phenylketonuria: a systematic review and meta-analysis. Orphanet J Rare Dis. 2015; 10: 17.

[28] Greeves LG, Carson DJ, Magee A, et al. Fractures and phenylketonuria. Acta Paediatr. 1997; 86: 242-244

[29] Walter JH. Vitamin B12 deficiency and phenylketonuria. Mol Genet Metab. 2011; 104(Suppl): S52-S54

[30] Al Hafid N, Christodoulou J. Phenylketonuria: a review of current and future treatments. Transl Pediatr. 2015; 4: 304-317.

[31] Crujeiras V, Aldámiz-Echevarría L, Dalmau J, et al. Vitamin and mineral status in patients with hyperphenylalaninemia. Mol Genet Metab. 2015; 115: 145-150.

[32] Bókay J, Kiss E, Simon E, et al. Maternal phenylketonuria. [Maternális phenylketonuria]. Orv Hetil. 2013; 154: 683-687. [Hungarian]

[33] Levy HL, Ghavami M. Maternal phenylketonuria: a metabolic teratogen. Teratology 1996; 53: 176-184.

[34] Koch R, Moseley K, Ning J, et al. Long-term beneficial effects of the phenylalanine-restricted diet in late-diagnosed individuals with phenylketonuria. Mol Genet Metab. 1999; 67: 148-155.

[35] Ney DM, Gleason ST, van Calcar SC, et al. Nutritional management of PKU with glycomacropeptide from cheese whey. J Inherit Metab Dis. 2009; 32: 32-39.

[36] Van Vliet D, Bruinenberg VM, Mazzola PN, et al. Large neutral amino acid supplementation exerts its effect through three syn- ergistic mechanisms: proof of principle in phenylketonuria mice. PLoS One 2015; 10: 0143833

[37] Pena MJ, de Almeida MF, van Dam E, et al. Protein substitutes for phenylketonuria in Europe: access and nutritional composition. Eur J Clin Nutr. 2016; 70: 785-789.

[38] Matalon R, Michals-Matalon K, Bhatia G, et al. Large neutral amino acids in the treatment of phenylketonuria (PKU). J Inherit Metab Dis. 2006; 29: 732-738.

[39] Spécola N, Chiesa A. Alternative therapies for PKU. J Inborn Errors Metab Screen. 2017; 5: 1-5.

[40] Blau N, Bélanger-Quintana A, Demirkol M, et al. Optimizing the use of sapropterin (BH4) in the management of phenylketonuria. Mol Genet Metab. 2009; 96: 158-163.

[41] Trefz FK, Burton BK, Longo N, et al. Efficacy of sapropterin dihydrochloride in increasing phenylalanine tolerance in children with phenylketonuria: A phase III, randomized, double-blind, placebo-controlled study. J Pediatr. 2009; 154: 700-707.el.

[42] Zurflüh MR, Zschocke J, Lindner M, et al. Molecular genetics of tetrahydrobiopterin-responsive phenylalanine hydroxylase deficiency. Hum Mutat. 2008; 29: 167-175.

[43] Muntau AC, Röschinger W, Habich M, et al. Tetrahydrobiopterin as an alternative treatment for mild phenylketonuria. $\mathrm{N}$ Engl J Med. 2002; 347: 2122-2132.

[44] Rohr F, Wessel A, Brown M, et al. Adherence to tetrahydrobiopterin therapy in patients with phenylketonuria. Mol Genet Metab. 2015; 114: 25-28.

[45] Longo N, Harding CO, Burton BK, et al. Single-dose, subcutaneous recombinant phenylalanine ammonia lyase conjugated with polyethylene glycol in adult patients with phenylketonuria: an open-label, multicentre, phase 1 dose-escalation trial. Lancet 2014; 384: 37-44

[46] Blau N, Longo N. Alternative therapies to address the unmet medical needs of patients with phenylketonuria. Expert Opin Pharmacother. 2015; 16: 791-800.

[47] Bottino R, Wijkstrom M, van der Windt DJ, et al. Pig-to-monkey islet xenotransplantation using multi-transgenic pigs. Am J Transplant. NIH Public Access. 2014; 14: 2275-2287.

[48] Soltys KA, Setoyama K, Tafaleng EN, et al. Host conditioning and rejection monitoring in hepatocyte transplantation in humans. J Hepatol. 2017; 66: 987-1000.

[49] Alexander IE, Cunningham SC, Logan GJ, et al. Potential of AAV vectors in the treatment of metabolic disease. Gene Ther. 2008; 15: 831-839.

[50] Grisch-Chan HM, Schlegel A, Scherer T, et al. Low-dose gene therapy for murine PKU using episomal naked DNA vectors expressing $\mathrm{PAH}$ from its endogenous liver promoter. Mol Ther Nucleic Acids 2017; 7: 339-349.

(Reismann Péter dr., Budapest, Szentkirályi u. 46., 1084 e-mail: reismann.peter@med.semmelweis-univ.hu)

\section{„Nihil magis aegris prodest, quam ab eo curari, a quo volunt." (Seneca) (A beteg javára válik, ha maga választja meg orvosát.)}

